\title{
Detection of Mycoplasma spp. from Choanal and Tracheal Samples using Genus Specific Polymerase Chain Reaction
}

\author{
A. A. Shingade ${ }^{1}$, R. S. Gandge 2 , S. B. Majee ${ }^{2}$, R. J. Zende ${ }^{3}$, \\ R. R. Pharande ${ }^{2}$ and S. A. Ingle ${ }^{1^{*}}$ \\ ${ }^{1}$ Animal Biotechnology Education and Research Cell, Department of Veterinary \\ Microbiology, Mumbai Veterinary College, Parel, Mumbai-400012 (India) \\ ${ }^{2}$ Department of Veterinary Microbiology, Mumbai Veterinary College, Parel, Mumbai- \\ 400012 (India) \\ ${ }^{3}$ Department of Veterinary Public Health, Mumbai Veterinary College, Parel, Mumbai- \\ 400012 (India), India \\ *Corresponding author
}

\section{Keywords}

Avian mycoplasma, genus specific PCR, choanal specimens, tracheal specimens, 16S rRNA,

Article Info

Accepted: 08 January 2020 Available Online: 10 February 2020

\section{A B S T R A C T}

Avian Mycoplasmosis is one of the most substantial global causes of economic losses to the poultry industry, particularly in chickens and turkeys. Present investigation was designed to detect Mycoplasma species from suspected broiler breeder/layer using genus specific Polymerase Chain Reaction (PCR). Hundred specimens including 50 each of choanal swabs and tracheal swabs were collected from five layer/breeder poultry farms from different areas of Maharashtra State. The swabs were inoculated in Pleuropneumonia Like Organism (PPLO) broth for isolation of Mycoplasma organisms. DNA extracted from specimens, broth cultures and reference strains (MG and MS) was amplified by 16S rRNA genus specific PCR yielding 714bp products. Out of 100, 44/50 (88\%) choanal swabs, $50 / 50(100 \%)$ tracheal swabs were found positive for Mycoplasma spp., while, from broth cultures, 45/50 (90\%) choanal swabs, 45/50 (90\%) tracheal swabs were found positive by PCR. The $48 \mathrm{hr}$. old broth cultures yielded better results than PCR from direct specimens. Current study showed that genus specific 16S rRNA PCR was found to be sensitive for detection of Mycoplasma spp. at genus level in direct specimens and broth cultures. Tracheal swabs were better specimens for investigation of Mycoplasma infection in poultry.

\section{Introduction}

The expansion of poultry sector has led to the establishment of many allied industries.
However, the poultry industry is facing multiple challenges due to increased morbidity and mortality of poultry caused by respiratory tract infections (Khatun et al., 
2018). Avian mycoplasmosis causes huge losses in broiler breeders due to reduced hatchability and egg production, stunted growth, increased cost of vaccination and medication and destruction of infected flocks under the National Poultry Improvement Plan of MG and MS clean programs (Khalifa et al., 2013).

Among the mycoplasma species that colonize avian hosts, four avian mycoplasmas are commonly recognized as poultry pathogens viz. M. synoviae (MS), M. gallisepticum (MG), M. iowae (MI) and M. meleagridis (MM) (Raviv and Kleven, 2009). Mycoplasma pullorum was isolated from a seventy two week-old layer hen (Beylefeld and Abolnik, 2017).

Also the various species of genus mycoplasma were recognized from chickens viz. $M$. gallinarum, $M$. gallisepticum, $M$. pullorum, M. gallinaccium, M. synoviae, $M$. iners (3\%), as well as one Acheoplasma laidlawii strain (Beylefeld et al., 2018). Nonpathogenic Mycoplasma species are generally overlooked, because they have less impact on bird health and production and provide evidence of multidrug resistance traits (Beylefeld et al., 2018).

Mycoplasma gallisepticum is a top ranking Mollicute, isolated from cases of chronic respiratory disease (Khatun et al., 2018), which can get rapidly transmitted both horizontally and vertically (Jarquin et al., 2009). MS causes infectious synovitis in both chicken and turkey and is also responsible for reduced egg production, poor growth and hatchability rate and significant condemnation of carcasses at slaughter (Marois et al., 2000).

Although, transmission of Mycoplasma synoviae by vertical transmission has major role in chickens (Lockaby et al., 1998, Kleven, 2003), transmission of MS via direct contact and respiratory aerosols is also reported (Hung-ChihKuo, 2016). The rapid and effective detection of mycoplasma is carried out by PCR based methods which have proven to be excellent for diagnosis of mycoplasmosis (Han Wang et al., 1997; Feberwee et al., 2005).

It is also a sensitive and specific technique which detects smallest amounts of DNA to a level that cannot be easily detected by other methods. Almost all species of the genera Mycoplasma, Spiroplasma, Acholeplasma and Ureaplasma can be detected by genus level PCR (Marois et al., 2002). PCR provides more advantage over conventional methods, as it helps to detect pathogenic agents in samples taken from asymptomatic birds undergoing antibiotic treatment and also in case of immunosuppression (Garcia et al., 1995; Kempf, 1998).

PCR is useful for detection of uncultivable pathogens directly from clinical samples and thus can replace conventional methods. It is considered to be more accurate, rapid and efficient for early identification of etiological agents (Hossam et al., 2016).

Present study was aimed to detect Mycoplasma spp. from breeder/layer at the genus level. Therefore, present study was aimed to test feasibility of using Polymerase Chain Reaction for identification of Mycoplasma spp. directly from the tissues or swabs collected from breeder/layer poultry flocks.

\section{Materials and Methods}

\section{Sample collection and preparation:}

A total of 100 samples comprising of 50 each of choanal cleft swabs and tracheal swabs from the unvaccinated birds against mycoplasmosis were processed. Investigation 
of five (05) layer/breeder poultry farms located in different regions of Maharashtra State was carried out for detection of Mycoplasma spp.

The specimens (choanal and tracheal swabs) were collected aseptically, in duplicates, from birds exhibiting either, history of disease, clinical signs, decreased egg production or reduced hatchability.

The swabs were placed in sterile leak-proof containers, packed in stout polystyrene foam containers and transported to the laboratory on ice (OIE, 2008).

\section{DNA Extraction}

The DNA from above clinical specimens were extracted as per the method described by Sambrook and Russell (2001). Briefly, the swabs were suspended in $0.5 \mathrm{ml}$ of TE buffer, with $20 \mu \mathrm{l}$ of Lysozyme $(20 \mathrm{mg} / \mathrm{ml})$ and incubated at $37^{\circ} \mathrm{C}$ for $1 \mathrm{hr}$.

The mixture was added with $200 \mu \mathrm{l}$ of $10 \%$ SDS and $20 \mu \mathrm{l}$ of proteinase-k $(20 \mathrm{mg} / \mathrm{ml})$ followed by incubation at $37^{\circ} \mathrm{C}$ for $2 \mathrm{hrs}$. Subsequently $200 \mu \mathrm{l} \mathrm{NaCl}(5 \mathrm{M})$ and $200 \mu \mathrm{l}$ CTAB (10\%) was added and incubated at $65^{\circ} \mathrm{C}$ for $20 \mathrm{~min}$.

Equal amount of P:C:I (25:24:1) was added to the suspension and centrifuged at 10,000 $\mathrm{rpm} / 10 \mathrm{~min}$ to extract the aqueous. Isopropanol $(100 \%)$ and $3 \mathrm{M}$ sodium acetate ( $\mathrm{pH} \mathrm{5.2)} \mathrm{in} 0.6$ and 0.1 volumes, respectively, was added. The mixture was left at $-20^{\circ} \mathrm{C}$ for at least $3 \mathrm{hrs}$ (or overnight) followed by centrifugation at $12000 \mathrm{rpm}$ for $10 \mathrm{~min}$ to collect the chromosomal DNA pellet.

Pellet was washed with $70 \%$ ethanol allowed to dry by keeping in incubator $\left(37^{\circ} \mathrm{C}\right)$ with lid open. The pellet was dissolved in $30 \mu \mathrm{l}$ of TE buffer/sterile milli-Q containing Rnase-A (20 $\mu \mathrm{g} / \mathrm{ml}$ ) and kept at $65^{\circ} \mathrm{C}$ for $1 \mathrm{hr}$ for proper dissolution and Rnase action. The isolated DNA was stored at $-20^{\circ} \mathrm{C}$ till further use.

\section{Cultural method}

The second set of samples, i. e. 50 specimens each of choanal and tracheal swabs were inoculated in Pleuropneumonia Like Organism (PPLO) MG and MS broth followed by providing the incubation conditions of $37^{\circ} \mathrm{C}$ temperature, $5 \% \mathrm{CO}_{2}$ upto $24-48 \mathrm{hrs}$.

Extraction of DNA from these broth cultures was performed as per the protocol described by Ley et al., (1997) and Sambrook and Russell (2001) with slight modifications if required. The bacterial ceels were pelleted by high speed centrifugation for 20 mins. DNA was extracted by the method described above.

\section{DNA Amplification}

The extracted DNA were subjected to PCR targeting the genus $16 \mathrm{~S}$ rDNA region of Mycoplasmal genome using the primers mentioned by Kuppeveld et al., (1992). The primer used were GPO-1 (5'-ACT-CCTACG-GGA-GGC-AGC-AGT-A -3') and MGSO (5'-TGC-ACC-ATC-TGT-CAC-TCTGTT-AACCTC -3').

PCR amplification was carried out in a $25 \mu \mathrm{l}$ reaction comprising of $12.5 \mu \mathrm{l}$ of $2 \mathrm{X}$ Mastermix (Takara Bio India Private limited), $0.4 \mu \mathrm{l}$ each of forward and reverse primers $(20 \mathrm{pmol} / \mu \mathrm{l}), 10.7 \mu \mathrm{l}$ nuclease free $\mathrm{H}_{2} \mathrm{O}$ and $1.0 \mu \mathrm{l}$ of template DNA $(50-100 \mathrm{ng} / \mu \mathrm{l})$.

Cycling conditions used for the amplification include: Initial denaturation at $95^{\circ} \mathrm{C}$ for $5 \mathrm{~min}$, $32 \mathrm{cCycles}$ of denaturation at $95^{\circ} \mathrm{C}$ for $1 \mathrm{~min}$, annealing at $54^{\circ} \mathrm{C}$ for $1 \mathrm{~min}$, extension at $72^{\circ} \mathrm{C}$ for 1 min and a final extension at $72^{\circ} \mathrm{C}$ for $5 \mathrm{~min}$. 
The PCR products were loaded on $2 \%$ agarose gel containing Ethidium bromide in final concentration of $0.5 \mu \mathrm{g} / \mathrm{ml}$ and electrophoresed @ 5V/cm of the gel. A 100bp DNA marker was electrophoresed simultaneously. The ensuing amplified DNA bands were visualised and documented using computerised automatic gel documentation device (Gel document EZ Imager, Bio-Rad).

\section{Results and Discussion}

Present study involved the diagnosis of avian mycoplasmosis in poultry directly from the clinical specimens viz. choanal and tracheal swabs. Mycoplasmas are fastidious organisms and difficult to propagate in vitro. Thus, polymerase chain reaction (PCR) can prove to be a better choice for accurate detection of the pathogen from clinical samples. Hundred samples (swabs) of choanal and tracheal regions were collected from live birds (Plates $1 \& 2$ ) showing symptoms of respiratory distress and also from apparently healthy birds. The presence of Mycoplasmas in the birds was determined using primers targeting the genus specific region 16S rDNA of Mycoplasma spp. The reference strains and

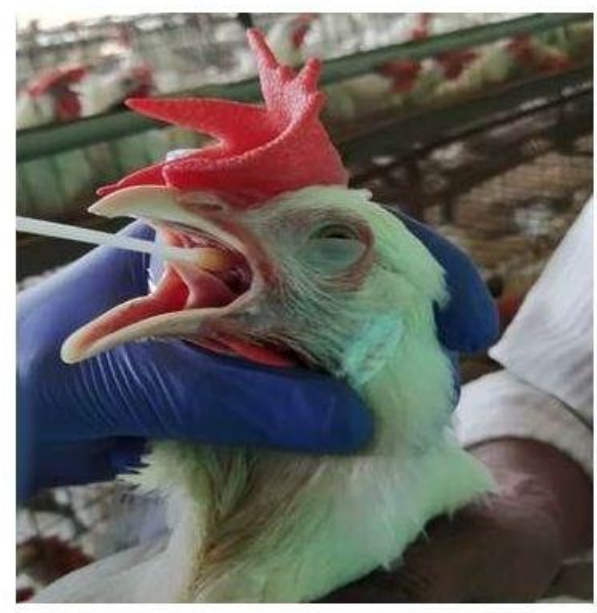

Plate.1 Collection of choanal cleft swab from live bird positive samples showed a band of $714 \mathrm{bp}$ suggesting an amplification of 16S rDNA region of the genome (Plates $3 \& 4$ ).

Out of 100 clinical specimens, 94 (94\%) were found positive by PCR and remaining $6(6 \%)$ were found negative. Out of these, $88 \%$ $(44 / 50)$ specimens of choanal swabs and $100 \%(50 / 50)$ of the tracheal swabs were found positive for Mycoplasma spp. A second set 100 samples (50 each of choanal and tracheal swabs) from same birds was enriched with PPLO MG and MS broth at $37^{\circ} \mathrm{C}$ under $5 \% \mathrm{CO}_{2}$.

The DNA extracted from these broth cultures were also subjected to PCR. Out of 100, 90 (90\%) were found positive in the genus specific PCR showing 714 bp amplicon and remaining $10(10 \%)$ were found to be negative.

Overall, 90\% (45/50) broth cultures each of choanal swabs and tracheal swabs were found positive for Mycoplasma spp. by PCR. The farm wise details of the samples collected and results of PCR are depicted in tables 1 and 2.

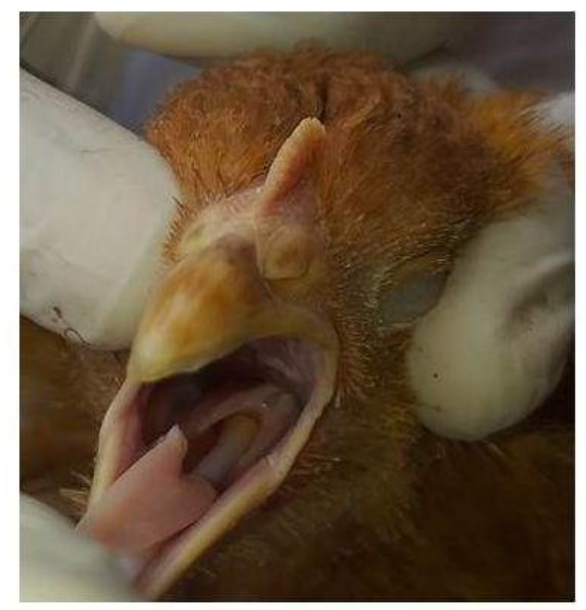

Plate.2 Collection of tracheal swab from live bird 


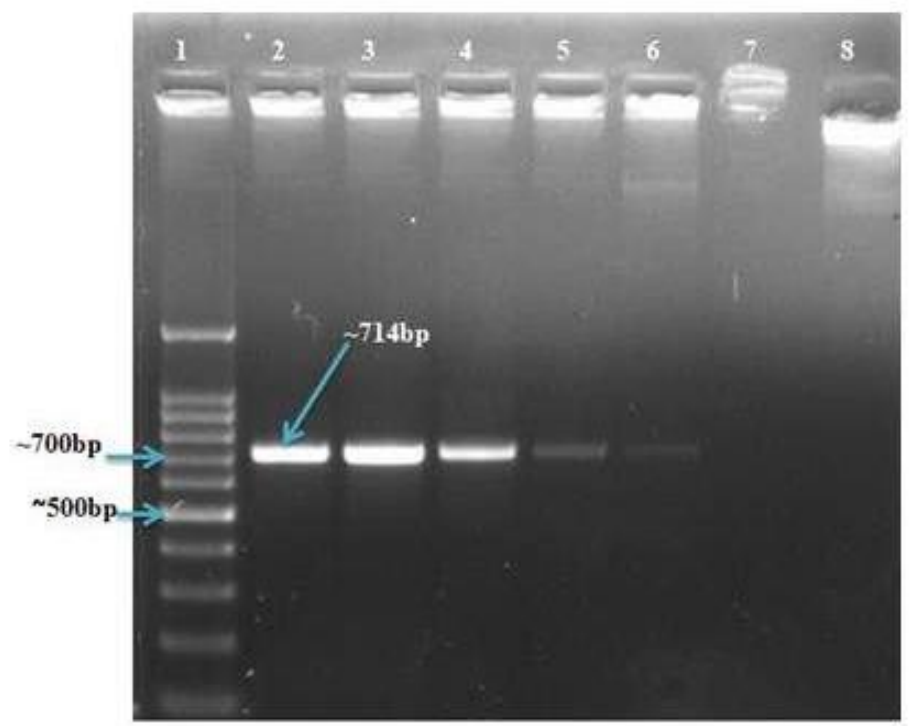

Lane 1- Ladder 100bp

Lane 2-Positive control (MG) Lane 7- Negative control

Lane 3-Positive control (MS) Lane 8-Non-template control

Lane 4-6- Positive samples

Plate.3 Genus specific 16S rRNA PCR of direct specimens

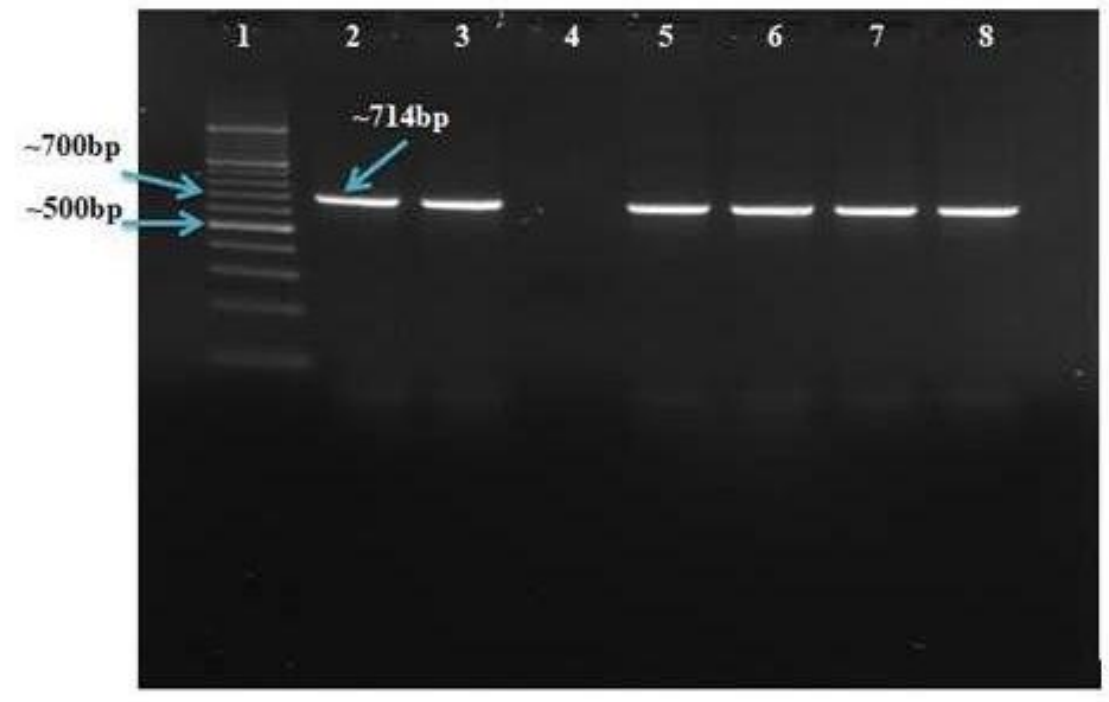

Lane 1- Ladder 100bp

Lane 2-Positive control (MG)

Lane 3- Positive control (MS)

Lane 4- Negative control

Lane 5-8 - samples

Plate.4 Genus specific 165 rRNA PCR of broth cultures 
Table.1 Molecular detection of Mycoplasma spp. in direct clinical specimens by PCR

\begin{tabular}{|c|l|c|c|c|}
\hline Source & $\begin{array}{c}\text { Type of } \\
\text { specimens }\end{array}$ & $\begin{array}{c}\text { No. of } \\
\text { specimens } \\
\text { processed }\end{array}$ & $\begin{array}{c}\text { No. of } \\
\text { specimens } \\
\text { Positive }\end{array}$ & $\begin{array}{c}\text { \% } \\
\text { specimens } \\
\text { Positive }\end{array}$ \\
\hline \multirow{2}{*}{ Farm 1 } & Choanal swabs & 05 & 04 & $80 \%$ \\
\cline { 2 - 5 } & Tracheal swabs & 05 & 05 & $100 \%$ \\
\hline \multirow{2}{*}{ Farm 2 } & Choanal swabs & 10 & 06 & $60 \%$ \\
\cline { 2 - 5 } & Tracheal swabs & 10 & 10 & $100 \%$ \\
\hline \multirow{2}{*}{ Farm 3 } & Choanal swabs & 10 & 10 & $100 \%$ \\
\hline \multirow{2}{*}{ Farm 5 } & Tracheal swabs & 10 & 10 & $100 \%$ \\
\hline & Choanal swabs & 10 & 09 & $90 \%$ \\
\cline { 2 - 5 } & Tracheal swabs & 10 & 10 & $100 \%$ \\
\cline { 2 - 5 } & Choanal swabs & 15 & 15 & $100 \%$ \\
\cline { 2 - 5 } & Tracheal swabs & 15 & 15 & $100 \%$ \\
\hline
\end{tabular}

Table.2 Molecular detection of Mycoplasma spp. in broth cultures by PCR

\begin{tabular}{|c|l|c|c|c|}
\hline \multirow{2}{*}{ Source } & $\begin{array}{c}\text { Type of } \\
\text { specimens }\end{array}$ & $\begin{array}{c}\text { No. of } \\
\text { specimens } \\
\text { processed }\end{array}$ & $\begin{array}{c}\text { No. of } \\
\text { specimens } \\
\text { Positive }\end{array}$ & $\begin{array}{c}\text { \% } \\
\text { specimens } \\
\text { Positive }\end{array}$ \\
\hline \multirow{2}{*}{ Farm 1 } & Choanal swabs & 05 & 05 & $100 \%$ \\
\hline \multirow{2}{*}{ Farm 2 } & Tracheal swabs & 05 & 05 & $100 \%$ \\
\hline \multirow{2}{*}{ Farm 3 } & Choanal swabs & 10 & 08 & $80 \%$ \\
\cline { 2 - 5 } & Tracheal swabs & 10 & 08 & $80 \%$ \\
\hline \multirow{2}{*}{ Farm 4 } & Choanal swabs & 10 & 09 & $90 \%$ \\
\cline { 2 - 5 } & Tracheal swabs & 10 & 07 & $70 \%$ \\
\hline \multirow{2}{*}{ Farm 5 } & Choanal swabs & 10 & 08 & $80 \%$ \\
\cline { 2 - 5 } & Tracheal swabs & 10 & 10 & $100 \%$ \\
\hline & Choanal swabs & 15 & 15 & $100 \%$ \\
\cline { 2 - 5 } & Tracheal swabs & 15 & 15 & $100 \%$ \\
\hline & Total & $\mathbf{1 0 0}$ & $\mathbf{9 0}$ & $\mathbf{9 0 \%}$ \\
\hline
\end{tabular}

Indian poultry sector is growing rapidly to provide required amount of food and animal proteins for society. In India commercial poultry is an important sector and with commercial sector, backyard poultry rearing is also increasing day by day.
However, the poultry sector is facing the problem of mycoplasma infection, which is to be addressed and taken care in order to reduce the economic losses in the industry and to poultry farmers. 
Vertical transfer of Mycoplasma is also a very critical problem in the layer/breeder stocks. Moreover, transfer of infection in the hatchery is significant problem in commercial farms. Therefore, the present investigation was carried out for detection of Mycoplasma infection in the layer/breeder birds.

In the present study, 100 direct clinical specimens were subjected to the Mycoplasma genus specific PCR, which yielded a total of 94 specimens positive for Mycoplasma spp. with an incidence rate of $94 \%$. Out of total 50 each specimens of choanal swabs, tracheal swabs a total of $44(88 \%)$ and $50(100 \%)$ respectively found positive by PCR.

Genus specific primers for Mycoplasma spp. identification are highly efficient and PCR is a consistent method commonly used for detection of poultry mycoplasmosis (Kupevald et al., 1992; Nehe, 2018). Various authors viz. Garcia et al., (1994), Fan et al., (1995), Kiss et al., (1997), Lienz et al., (2007), Tomar et al., (2017), Ghohestani et al., (2018) also used 16S rRNA gene for detection of Mycoplasma spp. infection in poultry. Fan et al., (1995) detected all Mycoplasma common species by the genus specific PCR by using 16S rRNA gene primer.

In the present study overall incidence of Mycoplasma spp. was found to be $94 \%$. However, lower percentage of Mycoplasma spp. incidence i.e. $27.3 \%, 36.95 \%, 31.25 \%$ and $50.4 \%$ was reported by Gondal et al., (2015), Tomar et al., (2017) Ghohestani et al., (2018) and Nehe (2018), respectively. The higher incidence of Mycoplasma spp. infection in the present study may be due to the improper managemental practices at the farms and the use of Mycoplasma free source of layer/breeder stocks.

The comparative results of choanal and tracheal swabs showed 44/50 (88\%) and $50 / 50(100 \%)$ positive samples in $16 \mathrm{~S}$ rRNA Mycoplasma genus specific PCR. Thus, the tracheal swabs were found to be better specimen for recovery and detection of Mycoplasma spp. Gondal et al., (2015) also observed similar results with highest positivity from tracheal samples who recovered total 27.3\% Mycoplasma spp. from tracheal swabs $(39.3 \%)$, tracheal tissue (15.9\%), lung tissue (27.4\%) and air sac (25\%). Khatun et al., (2018) investigated 48 samples for detection of $\mathrm{MG}$ from tracheal swabs, lung and air sac samples and found $25 \%, 6.25 \%$ and $6.25 \%$ samples, respectively, positive by PCR, and indicating highest recovery from tracheal swabs. Moreover, various workers also used tracheal swabs for investigation of mycoplasma infection viz. Kempf (1993), Carli and Eyigor (2003), Garcia et al., (2005), Lysnyansky et al., (2005) and Eissa (2009).

Out of 100 DNAs of $48 \mathrm{~h}$ old broth cultures, $90(90 \%)$ were found positive for the genus specific PCR and remaining $10(10 \%)$ were found to be negative. In the present study, the direct clinical specimens and broth cultures showed 94 (94\%) and 90 (90\%) samples positive, respectively, by $16 \mathrm{~S}$ rRNA genus specific PCR. The results yielded in direct specimens were higher than those in broth cultures. Similar results from 48 hrs old broth cultures were recorded by Hossam et al., (2016). They used three detection methods of MG and revealed that the highest recovery rate of MG was achieved by PCR on 48 hours incubation in PPLO broth $(70.9 \%)$, followed by direct PCR on infected tissue (65.45\%). Mardassi et al., (2005), Nehe (2018) also used the broth cultures incubated for 24-48 $\mathrm{h}$ and achieved better results for detection of mycoplasma infection.

Result from this study indicates that Mycoplasma genus specific 16S rRNA PCR was found to be sensitive for detection of 
Mycoplasma spp. at genus level in direct specimens and cultures. Tracheal swabs were found to be better specimens for investigation of Mycoplasma spp. infection in poultry.

It is feasible to directly use the clinical specimens from the birds for detection of mycoplasmosis. It requires less time and is cost effective. Enrichment of the samples, on the other hand, consumes more time and will also increase the cost of the investigation.

\section{References}

Beylefeld, A., P. Wambulawaye, D. G. Bwala, J. J. Gouws, O. M. Lukhele, D. B. Rudolph Wandrag and C. Abolnika (2018). Evidence for Multidrug Resistance in Nonpathogenic Mycoplasma Species Isolated from South African Poultry. Applied Environrnental Microbiology, 84 (13): $1-13$.

Beylefeld, A. and C. Abolnik (2017). Complete Genome Sequence of Mycoplasma pullorum Isolated from Domestic Chickens. Ammerican Society For Microbiology, 5(8): 1-2.

Carli. K. T. and A. Eyigor (2003) Real-Time Polymerase Chain Reaction for Detection of Mycoplasma gallisepticum in Chicken Trachea. American Association of Avian Pathologists, 47(3):712-717.

Eissa, S. I., S. A. El-Shater, M. A. Dardeer, E. E. Abd El Aziz, A. A. Hanaa and V. Anne, Gautier-Bouchardon (2009). Detection of Mycoplasma gallisepticum Infection in Day-Old Chicks Using Molecular Characterization. Mycoplasma Research Department, Animal Health Research Institute, Dokki, Egypt. 1357-1370.

Fan, H. H., S. H. Kleven, A. W. Jackwood, K. E. Johansson, B. B. Pettersson and S. Levisohn (1995). Species Identification of Avian Mycoplasmas by Polymerase Chain Reaction and Restriction Fragment Length Polymorphism Analysis. Avian diseases, 39: 398-407.

Feberwee, A., D. R. Mekkes, J. J. De Wit, E. G. Hartman and A. Pijpers (2005). Comparison of Culture, PCR, and Different Serologic Tests for Detection of Mycoplasma gallisepticum and Mycoplasma synoviae Infections. Avian diseases, 49(2): 260-268.

Garcia, M., M.W Jackwood, S. Levisohn and S.H. Kleven (1995). Detection of Mycoplasma gallisepticum , $M$. synoviae, and $M$. iowae by multispecies polymerase chain reaction and restriction fragment length polymorphism. Avian diseases, 39(3): 606-616.

Ghohestani, S., T. Zeinali, J. Razmyar, G. Kalidari and M. Bassami (2018). Isolation and Molecular Identification of Mycoplasma spp. From Pigeons in the North-East of Iran. Iranian Journal of Veterinary Medicine, 12(3), 181-187.

Gondal, M. A., M. Rabbani, K. Muhammad, T. Yaqub, M. E. Babar, A. A. Sheikh, A. Ahmad, M. Z. Shabbir and M. I. Khan (2015). Characterization of Mycoplasma gallisepticum isolated from commercial poultry flocks. The Journal of Animal \& Plant Sciences, 25(1): 108-113.

Han Wang, A. A. Fadl and M. I. Khan (1997). Multiplex PCR for pathogenic mycoplasmas. Molecular and Cellular Probes, 11: 211-216.

Hossam, M., A. Wagih, E. Mona, E. Mahmoud, E. Rehab and E. T. Salah (2016).The Recovery and Molecular Diagnosis of Mycoplasma gallisepticum Infection in Commercial Poultry Flocks in Egypt. Indian Journal of Science and Technology, 9(29): 1-8.

Jarquin, R., J. Schultz, I. Hanning and S. C. 
Ricke (2009). Development of a RealTime Polymerase Chain Reaction Assay for the Simultaneous Detection of Mycoplasma Gallisepticum and Mycoplasma Synoviae Under Industry Conditions. Avian Diseases, 53(1): 73-77.

Kempf, I., A. Blanchard, F. Gesbert, M. Guittet and G. Bennejean (1993). The polymerase chain reaction for Mycoplasma gallisepticum detection. Avian pathology, 22(4): 739-750.

Kempf, I. and F. Gesbert, (1998). Comparison of serological tests for detection of Mycoplasma gallisepticum antibodies in eggs and chicks hatched from experimentally infected hens. Veterinary microbiology, 60(2-4), 207213.

Khalifa, K. A., E. S. Abdelrahim, M. Badwi and A. M. Mohamed (2013). Isolation and Molecular Characterization of Mycoplasma gallisepticum and Mycoplasma synoviae in Chickens in Sudan. Journal of Veterinary Medicine.

Khatun, M., M. Rahman, S. R. Khan, K. Hossain and M. R. Akter (2018). Early Detection of Mycoplasma Gallisepticum using PCR from Field Samples in Layer Chicken. International Journal of Science and Business, 2(4): 699-706.

Kiss, I., K. Matiz, E. Kaszanyitzky, Y. Chavez and K. E. Johansson (1997). Detection and identification of avian mycoplasmas by polymerase chain reaction and restriction fragment length polymorphism assay. Veterinary Microbiology, 58(1): 23-30.

Kleven, S. H., R. M. Fulton, M. Garcia, V. N. Ikuta, V. A. Leiting, T. Liu, D. H. Ley, K. N. Opengart, K. N. Rowland and E. Wallner-Pendleton (2004). Molecular Characterization of Mycoplasma gallisepticum Isolates from Turkeys. Avian Diseases, 48: 562-569.

Kuo, H.C., D. Y. Lo, C. L. Chen, Y. L. Tsai,
J. F. Ping, C. H. Lee, P. Y. A. Lee and H. F. G. Chang (2016). Rapid and sensitive detection of Mycoplasma synoviae by an insulated isothermal polymerase chain reaction-based assay on a field-deployable device. Poultry science, 96(1): 35-41.

Ley, D.H. and H.W. Yoder, Jr. (1997). Mycoplasmosis. Mycoplasma gallisepticum infection. In Diseases of Poultry, 10th ed. Calnek. B.W., H.J. Barnes, C.W. Beard, L.R. McDougald, and Y.M. Saif, (eds.) Iowa State University Press, 194-207.

Lockaby, S. B., F. J. Hoerr, L. H. Lauerman and S. H. Kleven (1998). Pathogenecity of Mycoplasma synoviae in Broiler Chickens. Veterinary Pathology, 35:178-190.

Lierz, M., N. Hagen, N. Harcourt-Brown, S. J. Hernandez-Divers, D. Lu schow and H. M. Hafez (2007). Prevalence of mycoplasmas in eggs from birds of prey using culture and a genus-specific mycoplasma polymerase chain reaction. Avian Pathology, 36(2): 145-150.

Lysnyansky, I., M. Garcia and S. Levisohn (2005). Use of mgc2-Polymerase Chain Reaction-Restriction Fragment Length Polymorphism for Rapid Differentiation between Field Isolates and Vaccine Strains of Mycoplasma gallisepticum in Israel. Avian Diseases, 49: 238-245.

Marois, C., F. Oufour-Gesbert and I. Kempf (2000). Detection of Mycoplasma synoviae in poultry environment samples by culture and polymerase chain reaction. Veterinary Microbiology, 73: 311-318.

Marois, C., F. Dufour- Gesbert and I. Kempf (2002). Polymerase chain reaction for detection of Mycoplasma gallisepticum in environmental samples. Avian pathology,31(2): 163-168.

Mardassi, B. B. A., R. B. Mohamed, I. Gueriri, S. Boughattas and B. Mlik 
(2005). Duplex PCR to differentiate between Mycoplasma synoviae and Mycoplasma gallisepticum on the basis of conserved species-specific sequences of their hemagglutinin genes. Journal of clinical microbiology, 43(2): 948-958.

Nehe, S. G. (2018). Detection of Mycoplasma gallisepticum infection in chickens. (Post-graduation dissertation).

Raviv, Z. and S. H. Kleven (2009). The Development of Diagnostic Real-Time Taqman PCRs for the Four Pathogenic Avian Mycoplasmas. Avian Diseases 53(1):103-107.

Sambrook, J. and D. W. Russell (2008) Molecular cloning- A laboratory manual. Volume 2, 4th edition: 6.4

Tomar, P., Y. Singh, N. K. Mahajan, N. Jindal and M. Singh (2017). Duplex PCR for Direct Detection of Mycoplasma gallisepticum and Mycoplasma synoviae from Tissues of Poultry Affected with Respiratory Infections. International Journal of Livestock Research, 7(11).

Van Kuppeveld, F. J. M., J. T. M. Van Der Logt, A. F. Angulo, M. J. Van Zoest, W. G. V. Quint, H. G. M. Niesters, J. M. D. Galama and W. J. G. Melchers (1992). Genus and Species-Specific Identification of Mycoplasmas by $16 \mathrm{~S}$ rRNA Amplification. Applied And Environmental Microbiology, 58(8): 2606-2615.

World Organization For Animal Health (2008).Terrestrial Manual; 2.3.5:482496.

\section{How to cite this article:}

Shingade. A.A., R. S. Gandge, S. B. Majee, R. J. Zende, R. R. Pharande and Ingle. S.A. 2020. Detection of Mycoplasma spp. from Choanal and Tracheal Samples using Genus Specific Polymerase Chain Reaction. Int.J.Curr.Microbiol.App.Sci. 9(02): 1099-1108. doi: https://doi.org/10.20546/ijcmas.2020.902.128 